\title{
TÉRBELISÉG, ENDOGÉN NÖVEKEDÉS ÉS INNOVÁCIÓ ${ }^{1}$
}

\author{
(Geography, Endogenous Growth and Innovation) \\ ÁCS J. ZOLTÁN - VARGA ATTILA
}

\section{Bevezetö}

Tudományos kutatók, gazdaságpolitikusok és a közvélemény két évtizede felfokozott érdeklödéssel kíséri a kaliforniai Szilícium-völgyben végbement példa nélküli gazdasági fejlödést. Ezen fejlödés legföbb jellemzöjeként az innovációnak a régió egészét átható dominanciáját tekintjük. A Szilícium-völgy mindmáig meg nem haladott sikert ért el a számítógépek, szoftverek, félvezetök, biotechnológia és számos egyéb csúcstechnológiai iparág területén bevezetett és a termelést világszerte meghatározó innovációival. Természetesen a Szilícium-völgy nem az egyetlen régió a világon, amely az innovációk kiáramlásának forrása lenne, de mindenesetre kiváló példaként tünik annak igazolására, hogy az innovativitás meghatározó szerepú a régiók modernkori növekedésében.

A szakirodalomban egyre erősödö konszenzusnak lehetünk tanúi a tekintetben, hogy az innováció a gazdasági növekedés, az életszínvonal, a nemzetközi versenyképesség és a regionális fejlödés kulcstényezője. Számos, a regionális innovativitás okait kutató könyv jelent meg az utóbbi években (Braczyk-CookeHeidenreich 1998; de la Mothe-Pacquet 1998; Acs 2000). Habár a hivatkozott munkák eltérỏ megközelítéssel élnek, különböző módszertanra alapoznak, eltérö adatbázisra épülnek, és az elemzés alapegységét is különbözőképpen értelmezik, mégis egybehangzóan a regionális szint döntő szerepét sugallják. Elismerve a felsorolt munkák kétségtelen érdemeit, rá kell mutatnunk azonban arra is, hogy sem külön-külön, sem együttesen nem képesek a régiók innovativitásában meglevô jelentős különbségek magyarázatára.

Tanulmányunkban amellett érvelünk, hogy a regionális gazdasági növekedésben világszerte tapasztalható igen jelentös különbözőségek megértése céljából három alapvető és egymással igen szorosan összefüggő kérdés megválaszolása szükséges. Elöször is: miért és mikor kezd a gazdasági aktivitás koncentrálódni néhány régióban? Másodszor: mi a szerepe a technológiai fejlödésnek az eképpen beindult regionális gazdasảgi növekedés fenntartásában? Harmadszor: hogyan magyarázható a technológiai haladás, és melyek ennek legfontosabb folyamatai és intézményei? E három kérdés megválaszolása céljából három prominens és az utóbbi tíz évben egymástól függetlenül kifejlődött közgazdasági irányzat irodalmának áttekintésére vállalkozunk. Ezek: az új gazdaságföldrajz (Krugman 1991a; 1991b), a gazdasági növekedés új elmélete (Romer 1990) és az innováció új gazdaságtana (Nelson 1993). 
Ács J. Zoltán - Varga Attila : Térbeliség, endogén növekedés és innováció.

Tér és Társadalom 14. évf. 2000/4. 23-38. p.

24 Ács J.Zoltán - Varga Attila

TÉT XIV.évf. 2000

Tanulmányunk célja, hogy áttekintve a fenti három közgazdasági vonulatot közelebb kerüljünk a modernkori regionális növekedést meghatározó folyamatok megértéséhez. Míg mindhárom irányzat kétségtelenül sikeres a tekintetben, hogy bizonyos fényt vet a releváns kérdésekre, egyik sem képes megválaszolni a divergens regionális növekedés még nehezebb kérdését. Az új gazdaságföldrajz releváns magyarázattal szolgál ugyan a gazdasági koncentrációk kialakulására, de figyelmen kívül hagyja az innováció és a regionális növekedés problémáját. A gazdasági növekedés új elmélete megfelelö magyarázattal szolgál a növekedés okait illetöen, de nem tekinti kutatási területéhez tartozónak sem a regionális vonatkozásokat, sem az innovációt meghatározó kulcsfolyamatokat és intézményeket. Az innováció új gazdaságtana pedig, míg adekvát képet rajzol az intézményi berendezkedés innovációt meghatározó szerepét illetően, mind a regionális, mind a növekedéssel összefüggő kérdéseket figyelmen kívül hagyja.

Szándékunk szerint e három irányzat által a problémába mélyebb betekintést nyerve segítséget kapunk azon analitikus keret végiggondolásához, amely egy explicit termelési folyamat egészébe integrálva tárgyalja a gazdasági növekedés, a térbeni kölcsönös függóség és az új technológia létrejöttének problémáit, valamint képes arra, hogy segítséget nyújtson a termelésorientált regionális politikák kidolgozásához (Nijkamp-Poot 1997). A következö fejezetben az új gazdaságföldrajzot, a harmadikban az endogén gazdasági növekedés-elméletét, majd a negyedik fejezetben az innovációs rendszerek irányzatát tekintjük át. Tanulmányunkat rövid összefoglalással valamint néhány következtetés levonásával zárjuk.

\section{Tér és gazdaságelmélet}

Annak ellenére, hogy számos, a gazdasági folyamatok térbeliségével összefüggő probléma (mint például a vállalatok telephelyválasztása, a termelés egyenlötlen földrajzi eloszlásának jelensége, vagy a termelés koncentrációjából fakadó externáliák) mind gazdaságelméleti, mind gyakorlati szempontból döntő fontossággal bír, a térgazdaságtan (viszonylag rövid időperiódusokat kivéve) nem tudott a közgazdaságelmélet uralkodó irányzatának részévé válni. Elméleti gazdaságtani gondolkodásunkat még mindig egyfajta tér nélküli szemlélet határozza meg, egy szellemes megfogalmazás szerint a gazdaságot még mindig úgy képzeljük el, mintha minden folyamat egy „tü hegyén”, a térbeli távolság jelenléte nélkül zajlana. (Jellemzö, hogy a közgazdaságtanba bevezetö tankönyvek szerint a gazdaságelmélet által megválaszolandó három legfontosabb alapkérdés a Mit, Hogyan és a Ki számára, míg a Hol kérdésének a jelentősége fel sem merül.)

A térrel kapcsolatos jelenségek elhanyagolása különösen meglepö, ha figyelembe vesszük, hogy a térgazdaságtan történetének legjelentösebb eredményeit a közgazdaságtan általánosan elfogadott analitikus keretei között fogalmazták meg (Blaug 1979; Greenhut-Norman 1995; Krugman 1991a; 1995), tehát még egyfajta „szemantikai korlát" jelenlétéröl sem beszélhetünk. A telephelyelmélet megalapitója, Johann von Thünen például a differenciálszámítást jóval azelött alkalmazta, mielött 
az a közgazdaságtan meghatározó eszközévé vált volna (Blaug 1979; 1992), míg Alfred Weber telephelyelméletét a komparatív statika analitikus keretein belül fogalmazta meg (Weber 1929). Hasonlóan sem Walter Isard eröfeszítése a ,regionális tudomány" megalkotására (Isard 1956), sem Vernon Henderson törekvése a teoretikus városgazdaságtan létrehozására (Henderson 1985) nem vált tartósan a közgazdasági gondolkodás szerves részévé, annak ellenére, hogy mind az Isard-i, mind a Henderson-i elmélet a neoklasszikus gazdaságtan általánosan elfogadott paradigmáján belül került kidolgozásra.

A fenti dilemma lehetséges feloldásaként adódik az a feltételezés, hogy mivel a kezdetektől tér nélküli közgazdaságtan ,geografizálása” a rendszer alapjait érintő változásokat idézne eló a tudomány szerkezetében (Ohta 1988), az ilyen mértékü átépítéssel járó tetemes költségeket nem kívánja vállalni a közgazdaságtan kutató közössége - hasonlóan ahhoz, ahogyan bármely más tudomány kutató közössége cselekedne ilyen esetben (Kuhn 1984). A Paul Krugman (1991a; 1995) által ajánlott alternatív magyarázat szerint viszont minden korábbi térgazdaságtani kísérlet alapvető hibája, hogy elméleti rendszereik az álladó skálahozadék feltevésére épültek. Állandó skálahozadék mellett viszont megmagyarázhatatlan a gazdasági tevékenységek koncentrációja, így a nem tökéletes piaci verseny modellezésében a legutóbbi időkben végbement fejlődésig a közgazdaságtan fö irányának figyelmét a térgazdaságtani problémák elkerülték.

Tanulmányunk nem vállalkozik sem Krugman szerteágazó munkásságának elemzésére (e célt szolgáló munkák már megjelentek az irodalomban, lásd például Isserman 1996; Martin-Sunley 1996; Martin 1999), sem az úgynevezett „,́j gazdaságföldrajz" (new economic geography) dinamikusan fejlödő irányzatának részletes bemutatására. Azon célból, hogy a tudás-alapú regionális gazdasági növekedés megértése szempontjából a Krugman-i gondolatokban rejlő lehetőségeket feltárjuk, az alábbiakban röviden összefoglaljuk Krugman alapmodelljét.

Krugman, az amerikai gazdaságkutatók középnemzedékének egyik legkiemelkedőbb figurája a nemzetközi szakmai közvélemény kitüntetett figyelmét az ,új világgazdaságtan" megalapítójaként vonta magára. Azon felismerés, miszerint a gazdasági elemzés tényleges egységei nem az országok, hanem a régiók (hiszen a gazdasági folyamatok térbeli eloszlása korántsem az államok politikai határait követi) alapvetỏ motiváció Krugman térgazdaságtani orientációjának kialakulásában (Krugman 1991a; 1993c). Krugman a gazdasági aktivitás térbeli struktúrájának kialakulásához vezető okok magyarázatát a közgazdaságtan központi feladatának tekinti. Ezáltal határozottan szakít a közgazdaságtani fövonal eddig uralkodó tér nélküli szemléletével. Nagyhatású munkái révén az 1990-es évektől kezdödően egy igen erős térgazdaságtani kutatási irány bontakozik ki a mainstream közgazdaságtani irodalomban, amely önmagát (mintegy nyomatékosan elhatárolódva az alapvetöen deszkriptív és a matematikai modellezéstől magát kifejezetten távol tartó hagyományos gazdaságföldrajztól) „új gazdaságföldrajzként” határozza meg.

Krugman alapmodelljében (Krugman 1991a; 1991b; 1996) és annak folyamatos továbbfejlesztéseiben (Krugman 1993a; 1993b; 1996), valamint Fujita, Krugman és 
Ács J. Zoltán - Varga Attila : Térbeliség, endogén növekedés és innováció.

Tér és Társadalom 14. évf. 2000/4. 23-38. p.

Venables (1999) egy olyan általános egyensúlyi elméletet dolgoz ki, amely a gazdasági folyamatok térbeli koncentrációját három tényezö, a növekvö skálahozadék, a szállítási költség és az ipari termékek iránti kereslet kölcsönhatásai révén magyarázza. A modell szerint a három paraméternek bizonyos határértékeket kell elérni annak érdekében, hogy a gazdaság térbeli koncentrációját eredményező folyamatok beinduljanak. Hasonlóan az ,új világgazdaságtan"-hoz (,,new international trade theory") és a „gazdasági növekedés új elméleté"-hez (,new/endogenous economic growth theory") Krugman elméletének egyik alapköve a Dixit és Stiglitz-féle (Dixit-Stiglitz 1977) monopolisztikus verseny modell.

Eltekintve a természetből származó inputok egyenlötlen térbeli eloszlásának területi koncentrációkat generáló hatásaitól, a gazdasági folyamatok földrajzi sürüsödésének alapfeltétele a növekvő skálahozadék jelenléte az ipari termelésben (ellenkezö esetben nem lenne gazdaságos vállalni a szállitási költségeket a fogyasztás távoli pontjaira). Mindazonáltal a szállitási költségek egy megfelelően alacsony mértéke nélkül még növekvő skálahozadék megléte esetén sem indulnak el a koncentráció felé mozdító folyamatok, és az ipari termelés a kereslet eloszlását fogja követni. Abban az esetben, ha a szállitási költségek és a növekvö hozadék megfelelö szintjei kialakulnak, az ipari termelés elkezd koncentrálódni azokon a területeken, ahol már a kereslet egy viszonylag magas foka kialakult (eképpen is csökkentve a szállítási költségeket). Keresleti és kínálati externhatások (Hirschman 1958) a koncentrálódás fokozódását eredményezik: az ipari termelök oda települnek, ahol a kereslet magas és már megfelelő inputkínálat van jelen. Mindezeken felül a keresleti és kínálatiextern hatások egyfajta pozitív visszacsatolásos folyamaton keresztül (,cumulative causation”, ahogyan Myrdal [1957] fogalmaz) tovább erösítik a már kialakult koncentrációkat: az új termelök letelepülése növeli a már meglévő externhatásokat, és a régióba való további betelepülést generál. A következökben röviden összefoglaljuk Krugman kétrégiós modelljét (Krugman 1991a; 1991b).

Az egyéni fogyasztói választásokat a következö Cobb-Douglas-tipusú hasznossági függvény determinálja:

$$
\mathrm{U}=\mathrm{C}_{\mathrm{M}}{ }^{\pi} \mathrm{C}_{\mathrm{A}}{ }^{1-\pi}
$$

ahol $C_{M}$ az aggregátumként értelmezett ipari termékek fogyasztását, $\mathrm{C}_{\mathrm{A}}$ a mezőgazdasági termékek fogyasztását és $\pi$ az ipari termékek vásárlására fordított kiadásokat reprezentálja.

Az ipari termékek aggregát kereslete az alábbi CES függvényt követi:

$$
\mathrm{C}_{\mathrm{M}}=\left[\Sigma_{\mathrm{i}} \mathrm{C}_{\mathrm{i}}^{(\sigma-1) / \sigma}\right]^{\sigma /(\sigma-1)}
$$

ahol $\sigma>1$ az $\mathbf{n}$ darab ipari termék helyettesítés rugalmassága. Ha n megfelelóen nagy, akkor $\sigma$ egyben a kereslet rugalmasságát is képviseli (Krugman 1980).

A modell feltételezései szerint az ipari termelést növekvő skálahozadék, míg a mezőgazdasági javak elóállitását állandó skálahozadék jellemzi. Az ipari termelés költségeit munkában kifejezve a következő képletet adja meg:

$$
\mathrm{L}_{\mathrm{Mi}}=\alpha+\beta \mathrm{x}_{\mathrm{Mi}}
$$


ahol i jelöli az iparvállalatokat, $\alpha$ a fix költségek paramétere, $\beta$ a határköltség paramétere és $\mathrm{x}_{\mathrm{Mi}}$ a termelés outputja.

Monopolisztikus verseny esetén az i-edik termék egyensúlyi ára a következőképpen alakul:

$$
P_{\mathrm{i}}=[\sigma /(\sigma-1)] \beta \mathrm{w}
$$

amelyböl következik, hogy (mivel $\mathrm{P}_{\mathrm{i}}=\mathrm{AC}_{\mathrm{i}}$, és $\beta \mathrm{w}$ a határköltséget reprezentálja) az átlagköltség és a határköltség hányadosa $(\mathrm{AC} / \mathrm{MC}-$ a vállalat méretének egyfajta mutatója) $\sigma /(\sigma-1)$-el egyenlö. Következésképpen $\sigma$ egyben a skálahozadék mértékének inverz indexe (ugyanis minél nagyobb a $\sigma$, annál nagyobb a vállalat mérete amit az mutat, hogy az AC/MC egyre kisebb -, és a vállalat egyre közelebb kerül az állandó skálahozadékkal jellemzett üzemmérethez).

Miután a modell két kulcs-paramétere (a $\pi$ és a $\sigma$ ) definiálásra került, már csak a harmadik, a szállítási költségek bevezetése maradt hátra. A szálítás költségei a Samuelson-féle ,jéghegy-elv" alapján épülnek be a modellbe: a távolság növekedésének arányában a termék célbajuttatott hányada egyre kisebb lesz (a termék a szállítás közben mintegy elolvad, ahogyan a jéghegyek is elolvadnak dél felé haladva). A fogyasztóhoz megérkezett termék-részt a $\tau$ paraméter jelöli.

A modell feltételezései szerint a gazdaság két régióból áll: Keleten az ipar dominál, míg Nyugaton kizárólag mezögazdasági termelés folyik. $\pi$ az ipari termelők aránya Keleten. A térben rögzített termelési tényezőként definiált mezőgazdasági

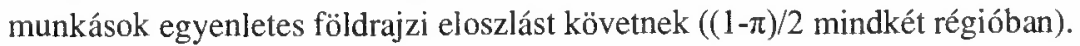

A modell (a probléma rendkívüli bonyolultsága okán) nem vállalkozik a két régió kialakulásának dinamikus tárgyalására. Ehelyett, indirekt megoldást választva, azokat a feltételeket kutatja, amelyek a fennálló térbeli struktúra lebontását idézik elő. Mindez a modellben azon kondíciók keresését jelenti, amelyek mellett egy reprezentatív vállalat úgy dönt, hogy Keletről Nyugatra költözik. K-val jelölve a Nyugaton és Keleten elérhető értékesítési bevételek arányát, ha $\mathrm{K}>1$, akkor a vállalat telephelyet változtat. Mindez a modell formalizált nyelvén a következöképpen nyer kifejezést:

$$
\mathrm{K}=\mathrm{S}_{\mathrm{w}} \tau^{-\pi} / \mathrm{S}_{\mathrm{E}}=1 / 2 \tau^{\pi \sigma}\left[(1+\pi) \tau^{\sigma-1}+(1-\pi) \tau^{-(\sigma-1)}\right]
$$

ahol $S_{w}$ és $S_{E}$ a Nyugaton és Keleten elért árbevételeket reprezentálja, míg $\tau^{-\pi}$ az árindex. K-t parciálisan deriválva és az eredményt a $\mathrm{K}=1$ környezetében értékelve a (2.5)-ös egyenlet bemutatja a modell fö paramétereinek hatását a vállalat lokációs döntésére. $A(2.5)$-ös egyenlet szerint $\partial K / \partial \pi<0$ (vagyis: az ipari értékesítés növekedése koncentrációt generáló hatású), $\partial \mathrm{K} / \partial \sigma>0$ (vagyis: minél kisebbek a méretgazdaságosság elönyei, annál nagyobb az ösztönzés a relokációra), valamint a koncentráció és nem-koncentráció határán kalkulálva $\partial \mathrm{K} / \partial \tau<0$ (vagyis: a szállítási költség csökkenése a koncentrációk kialakulását segíti elö).

$\mathrm{K}=1$ mellett a (2.5)-ös egyenlet lehetőséget ad a három paraméter értékeinek számítógépes szimulálására, ahogyan ezt az 1. ábra is illusztrálja. A két görbe a $\sigma$ különböző értékei mellett $\left(\sigma_{1}<\sigma_{2}\right)$ a térbeli koncentráció és az egyenletes földrajzi eloszlás közti határt reprezentálja. A $\pi$ és $\tau$ értékeinek olyan kombinációi, amelyek 
Ács J. Zoltán - Varga Attila : Térbeliség , endogén növekedés és innováció.

Tér és Társadalom 14. évf. 2000/4. 23-38. $p$.

(adott $\sigma$ mellett) a görbe feletti tartományba esnek, a termelés térbeli koncentrációjának paraméterfeltételeit jelentik. Ahogyan azt az 1. ábra is mutatja, a méretgazdaságosságból fakadó jelentős elönyök, az alacsony szállitási költség és az ipari értékesítés magas arányának bizonyos kombinációi a gazdaság térbeli koncentrálódását fogják előidézni. A gazdaság eképpen megalkotott térbeli modelljét Krugman (1993a; 1993b) valamint Fujita, Krugman és Venables (1999) a kettőnél is több régió eseteire is kiterjesztette.

\section{1. ÁBRA}

A térbeli koncentrációk kialakulásához vezetö paraméterkombinációk Krugmannál (The Combination of Parameters Leads Geographical Concentration in Krugman's View)

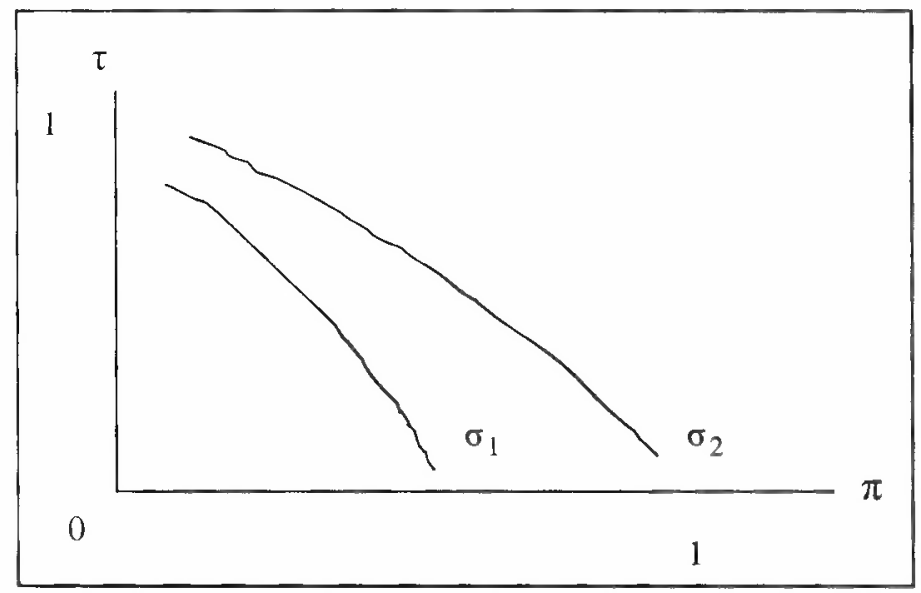

Forrás: Krugman 1991b, 498. o. alapján.

A gazdasági koncentrációk kialakulásának feltételeit kutató Krugman-i modell újszerüsége nem a modell elemeiben, hanem abban a speciális módban áll, ahogyan a rendszert Krugman felépítette. Az az állitás, hogy a csökkenő szállítási költségek, a méretgazdaságosság és az ipari termékek iránti növekvő kereslet pozitívan hat a gazdaság térbeli koncentrálódására korántsem tekinthetô újnak, hiszen mindezzel a gazdaságföldrajz vagy a regionális közgazdaságtan irodalmában már korábban is gyakran találkozhattunk. Hasonlóan, a keresleti és kínálati externáliák, valamint az azok által kiváltott pozitív visszacsatolásos folyamatok már részletes megfogalmazást nyertek Myrdal (1957) és Hirschman (1958) munkáiban. Mindazonáltal az a megoldás, ahogyan ezeket az elemeket Krugman egy általános egyensúlyi modellbe szervezi, minden kétséget kizáróan eredeti. A modell a térgazdaságtan egyik igen fontos problémáját egy olyan gondolati rendszerben magyarázza, amely a modern közgazdaságtan müvelöinek széles körei számára is elfogadható. Krugman ezen modelljével (és ennek folyamatos kiterjesztéseivel) a kutatások olyan módszerét alapozza meg, amely igen rövid idó alatt a térgazdaságtani problémákkal való foglalkozást újra a közgazdaságtan fö vonalába („mainstream economics”) emelte. 
Ács J. Zoltán - Varga Attila : Térbeliség , endogén növekedés és innováció.

Tér és Társadalom 14. évf. 2000/4. 23-38. p.

Térbeliség, endogén ...

A modell tehát egy olyan technikát kínál, amely a gazdasági folyamatok térbeli koncentrálódásának magyarázatát néhány paraméter kiinduló kombinációinak következményeként írja le. Mindazonáltal a modell jelenlegi formája nem tünik alkalmasnak arra, hogy a tudás-bázisú regionális növekedés magyarázatául szolgáljon. Elöször is Krugman határozott ragaszkodása ahhoz, hogy tartózkodjék a technológiai externáliák (tudás szpillóverek) beépítésétől a modellbe, megakadályozza azok használatát az innovációk által generált regionális növekedés magyarázatára. Másodszor, míg a modell igen jól kidolgozott abban a tekintetben, ahogyan az a koncentrációk induló feltételeit megadja, a gazdasági növekedés leírásában már kevésbé tekinthető hasonlóan részletezettnek. A Myrdaltól és Hirschmantól átvett visszacsatolásos folyamatok implicit beépítése nem tünik elégségesnek a divergens regionális növekedés magyarázatára.

\section{Endogén technikai fejlödés}

Tanulmányunk most következö fejezete korántsem tekinthető az endogén gazdasági növekedés igen szerteágazó irodalmának bemutatásaként (erre igen kiváló munkák állnak rendelkezésre, mint pélđául Grossman-Helpman 1991; Helpman 1992; Romer 1994; Barro-Sala-i-Martin 1995; Nijkamp-Poot 1997; AghionHowitt 1998). Az alábbiakban kizárólag arra vállalkozunk, hogy az elmélet azon oldalait emeljük ki, amelyeknek potenciálisan meghatározó jelentősége lehet tanulmányunk célja szempontjából.

Összehasonlítva a neoklasszikus növekedés-elmélettel az endogén elméletek a technológiai fejlődést profit-motiválta egyéni đöntések eredményeként magyarázzák, s ezáltal azt endogénként kezelik. A technikai tudás újszerü felfogása Romernél (1990) kulcsként tekinthetö a gazdasági növekeđés új és rendkívül dinamikusan gazdagodó irodalmának kialakulásában. Eszerint a technológiai tudás nem-versenyző (,,non-rival”) és annak fogyasztásából másokat csak részben kizáró (,partially excludable”) jószág. A technológiai tudás ezen megfogalmazása az állanđó hozađékkal és tökéletes piaci versennyel jellemzett neoklasszikus világgal való határozott szakítást jelez.

A termelési függvény központi helyet foglal el a Solow (1956) által megfogalmazott neoklasszikus növekedés-elméletben. Kiindulásképpen eltekintve a tőke amortizációjától, valamint feltéve, hogy sem a munka tömege, sem a technológia nem változik (Helpman 1992) a termelési függvény a következö formát ölti:

$$
\mathrm{Y}=\mathrm{F}(\mathrm{K}, \mathrm{L})
$$

ahol $\mathrm{Y}$ az aggregát termelés, $\mathrm{K}$ a tỏkekészlet és $\mathrm{L}$ a munka tömege. $\mathrm{F}(\bullet)$ a termelés állanđó skálahozadékkal jellemzett függvénye. A (3,1)-es egyenletben feltesszük, hogy a töke készlete folyamatosan, határok nélkül növekszik. Mindazonáltal az egy före jutó jövedelem növekedése korlátozott, ahogyan az az alábbi egyenletből is következik.

$$
\mathrm{g}=\mathrm{s} \mathrm{F}_{\mathrm{K}}(\mathrm{K}, \mathrm{L})
$$


Ács J. Zoltán - Varga Attila : Térbeliség, endogén növekedés és innováció.

Tér és Társadalom 14. évf. 2000/4. 23-38. p.

30 Ács J. Zoltán - Varga Attila

TÉT XIV. évf. 2000

ahol $g$ az egy före jutó jövedelem növekedési rátája, $s$ a megtakaritási ráta és $F_{K}$ a töke határterméke. A (3.2)-es egyenlet szerint az egy före jutó jövedelem addig növekszik, míg a töke határterméke nagyobb nullánál. Mindazonáltal a tökekészlet folyamatos bövülése miatt $F_{K}$ fokozatosan csökken, s így az egy före jutó jövedelem növekedése végül is a nullához tart. (Fontos figyelembe venni, hogy ez a végkövetkeztetés még abban az esetben is fennmarad, ha a stabil munka és nulla amortizáció feltevését feloldjuk.) Következésképpen az egy före jutó jövedelem hosszú távon fenntartható növekedése a tökekészlet folyamatos bövülése mellett csak akkor valósulhat meg, ha $\mathrm{F}_{\mathrm{K}}$ nem válik nullává.

A technológiai fejlödés igen fontos szerepet játszik a töke-akkumuláció következtében az egy före jutó jövedelem csökkenő ütemü növekedésének ellensúlyozásában. A technológiai fejlödést is beépítve a fenti modellbe a termelési függvény a következő általános alakot ölti:

$$
\mathrm{Y}=\mathrm{F}(\mathrm{A}, \mathrm{K}, \mathrm{L})
$$

ahol $\mathrm{A}$ a technológia adott állapotát jelzö változó. A folyamatos növekedése a töke határtermékének emelkedését váltja ki, ami magasabb egy före jutó jövedelmet eredményez. Következésképpen a hosszú távú egyensúlyi növekedés állapotában a technikai fejlödés rátája megegyezik a töke akkumuláció rátájával.

A fentiek a techológiai fejlődésnek a gazdasági növekedésben játszott alapvetö szerepét bizonyítják. Mindazonáltal a technológiai fejlödés megmagyarázatlanul marad a neoklasszikus növekedés-elméletben: mint közösségi jószág a technológia adott állapota a modellen kívül, exogén módon határozódik meg. A neoklasszikus elmélet ezen jellemzője egy kétségtelen paradoxont rejt magában, hiszen ahogy Solow (1957) és Maddison (1987) empirikus elemzései is tanúsítják, a gazdasági növekedés legnagyobb hányada az exogénnek tekintett technológiai fejlödésből adódik, míg a modell fö magyarázó változójának tekintett töke-akkumulációból a növekedésnek pusztán egy kisebb részaránya következik.

A gazdasági növekedés irodalmának legjelentösebb kísérletei a technológiai fejlődés endogenizálására Arrow (1962), Romer (1986) és Lucas (1988) nevéhez füződnek. Arrow szerint a technológiai fejlödés a ,gyakorlat általi tanulás” (,learning by doing”) következménye, míg Romer a kutatások modellezésével, Lucas pedig az emberi tőke révén endogenizálja a technológiai fejlődést. Arrow megfogalmazásában a technológia állapota az aggregát tơkeállomány függvénye:

$$
Y_{i}=A(K) F\left(K_{i}, L_{i}\right) \text {, }
$$

ahol i az egyes vállalatokat jelöli. A Lucas-i modell szerint az emberi tỏkeberuházások által eredményezett szpillóverek a technikai fejlődés fö motorjai:

$$
Y_{i}=A(H) F\left(K_{i}, L_{i}\right) \text {, }
$$

ahol H az emberi töke általános szintjét képviseli a gazdságban. Romer (1986) szerint az ipari kutatásokból eredő szpillóverek vezetnek a mindenki által hozzáférhetö technológiai tudás készletének kialakulásához:

$$
Y_{i}=A(R) F\left(R_{i}, K_{i}, L_{i}\right) \text {, }
$$


ahol $R_{i}$ az i-edik vállalat privát kutatási és fejlesztési $(\mathrm{K}+\mathrm{F})$ erőfeszitéseiböl eredö tudást reprezentálja, míg $\mathrm{R}$ a közössségileg rendelkezésre álló kutatási eredmények készlete.

Romer (1990) szerint az endogén növekedés (3.4)-(3.6) általi megfogalmazásainak alapvetö koncepcionális problémája abban áll, hogy mindhárom elmélet a rendelkezésre álló tudáskészlet egészét közösségi jószágnak tekinti. Mindez szemben áll azzal az akár mindennapinak is nevezhetö tapasztalattal, hogy az újonnan kifejlesztett technológiai tudás a szabadalmi bejelentések által (ha csak egy bizonyos ideig is) részben másokat kizáróvá tehetö. Következésképpen bármely, az új technológiai tudást bővítő vállalat monopolista profitra válthatja a csakis általa birtokolt tudásból származó piaci hatalmat. A Romer (1990) által megalapozott „új gazdasági növekedés-elmélet" a technológiai tudásnak a fentiektől eltérő koncepcióját dolgozza ki, s a növekedés modelljét a nem-tökéletes piaci verseny feltételei mellett építi fel.

A monopolista verseny Dixit és Stiglitz (1977) által kidolgozott modelljét Judd (1985) alkalmazta elöször a gazdasági növekedés modellezésében. Romer (1990) a Judd-féle megoldást kombinálta a „gyakorlat által tanulás" elvével, s ezáltal az első, a nem-tökéletes piaci verseny keretfeltétele mellett kidolgozott endogén növekedéselméletet alkotta meg. Az elmélet középpontjában a technológiai tudásnak mint nem-versenyzö, de ugyanakkor részben másokat kizáró jószágnak a felfogása áll. A tudás nem-versenyző jószág, mivel annak használata elvben nem akadályozza a mások általi fogyasztást, de ugyanakkor részben másokat kizáró is, mivel lehetöség van a fogyasztók körének korlátozására. Ez a nézet gyökeresen különbözik a neoklasszikus növekedés-elmélet nézetétől, mely szerint a tudás tisztán közösségi jószág.

A tudás a termelésbe kétféle módon kapcsolódhat be. Elöször is, az újonnan kifejlesztett tudás termelési tényezövé válik az azt kidolgozó vállalat számára. Ebben a minőségében a tudást a vállalat feltehetöleg igyekszik másoktól elzárni, például szabadalmaztatás által. Mindazonáltal ez az új tudás növeli a közös fogyasztásra rendelkezésre álló javak körét, mivel (annak legalábbis egy része) a szabadalmi dokumentumok tanulmányozása révén mások által is felhasználhatóvá válik. Ezen tudás-szpillóver révén a vállalat által végzett kutató-fejlesztő tevékenység növeli a többi vállalat kutatási hatékonyságát is. A tudásnak ezt a második szerepét a következőképpen formulázza Romer (1990):

$$
\mathrm{dA}=\mathrm{G}(\mathrm{H}, \mathrm{A})
$$

ahol $\mathrm{H}$ a kutatás-fejlesztésben használt emberi töke, $\mathrm{A}$ a szabadon rendelkezésre álló technológiai tudás teljes mennyisége, míg $\mathrm{dA}$ a technológiai szint változása, melynek alapja a kutatás-fejlesztésre fordított privát beruházás. Az emberi töke állítja elö az új tudást, ám az emberi tőke produktivitása a rendelkezésre álló technológiai tudás mennyiségétöl (A) függ. Minél nagyobb A értéke, annál produktívabb H, és annál kisebb költséggel lehet az új technológiai tudást elóállítani.

Az endogén növekedés-elmélet egyik legfontosabb alapfeltevése abban áll, hogy a tudás azon része, amely közösségi jószágnak minösül (A) bárki számára rendelkezésre áll. Meg kell azonban jegyezni, hogy ez az állitás nem nyert megerösitést sem a tudás szpillóverek igen dinamikusan fejlödő empirikus irodalmában (lásd például Jaffe 1989; Acs-Audretsch-Feldman 1991; 1994; Glaeser és szerzötársai 1992; 
Ács J. Zoltán - Varga Attila : Térbeliség , endogén növekedés és innováció.

Tér és Társadalom 14. évf. 2000/4. 23-38. p.

Anselin-Varga-Acs 1997; Varga 1998; 2000), sem az innovációs rendszerekröl szóló tanulmányokban (például Saxenian 1994; Braczyk-Cooke-Heidenreich 1998; Oinas-Malecki 1999; Stemberg 1999; Acs 2000; Fischer-Varga 2001). Az új technológiai tudás (ami természetszerủleg a legértékesebb tudás az innováció folyamatában) általában még nem kodifikált, s pusztán személyes kapcsolatok által közvetíthető. A személyes kapcsolatok gyakoriságának viszont gátat szab a térbeli távolság, következésképpen a legújabb tudás áramlása a térben korlátozott.

Ahhoz hasonlóan, ahogy Romer (1994) feloldotta a tudáshoz való hozzáférhetóség egyenlő esélyének neoklasszikus feltételezését az egyes országok viszonylatában, a realításhoz jóval közelebb álló modellezés érdekében szüikségesnek látszik ama feltevés feloldása is, miszerint a tudás közösségi része (A) a térben egyenletes eloszlást mutat. Úgy tünik tehát, hogy a tudás azon halmaza, amelyet nem másokat kizárónak nevezünk két részhalmazra bontható: a tökéletesen hozzảférhető részre, amely tudományos publikációk, szabadalmi dokumentumok tanulmányozása révén bárki számára hozzáférhetö és az eredetien új, de ugyanakkor még nem kodifikált, rejtett tudásra, amely pusztán a tudás befogadásához szükséges ismeretekkel rendelkezök személyes kapcsolatai által transzferálható. Míg az első halmazba tartozó tudáselemek bárki számára megszerezhetőek, a második halmaz elemeihez való hozzáférés korlátozott az innovációs rendszer szereplöi közti interakciók természete által.

\section{Az innováció rendszerei}

Tanulmányunk megelöző két fejezetét formalizált modellek alkották. Az innovációs rendszereknek az utóbbi tíz évben kifejlődött tudományos irányzatát viszont korántsem a formális megközelítés jellemzi, s mint ilyen, módszerét nem a matematikai változók egymás közötti viszonyainak elemzése alkotja. A legtöbb, amire ebben a vonatkozásban ez az irányzat vállalkozhat az az, hogy alapot szolgáltasson ama feltevés számára, miszerint a technológiai innováció meglehetỏsen nagyszámú tényezỏ által determinált folyamat. Az innovációs rendszerek irányzata - hasonlóan egyéb, az institucionalizmus által befolyásolt irányzathoz - egy gondolkodási keret, amely az innováció elemzésében jól használhatónak bizonyult mind a tudomány képviselöi, mind az innováció-politikával foglalkozók számára (Edquist 1997). Habár az innovációk rendszerének irányzata nem tekinthetö formalizált és megalapozott elméletnek, annak kialakulására kétségtelenül hatást gyakoroltak olyan innováció-elméletek, mint az interaktív tanulás teóriája (Arrow 1962), vagy az evolucionarizmus elmélete (Nelson-Winter 1982).

$\mathrm{Az}$ új Schumpeteriánius evolucionarista gazdaságtan tradícióján belül jelentös eredmények szuilettek az innováció alapjainak megértése tekintetében. Nelson és Winter An Evolutionary Theory of Economic Change (1982) címü munkája valószínủleg e tradíció próbaköve. Az elmúlt évek erőfeszítései arra irányultak, hogy az evolucionarista gazdaságtan elméleti és empirikus megfigyeléseit egy olyan koncepcionális keretbe szürjék át, amely a lazán értelmezett „nemzeti rendszer” gondolata körül szervezödve alkalmassá válik innováció-politikai lépések támogatására. 
Annak ellenére, hogy az innovációs rendszerek különbözö irányzatai eltérỏen értelmezik az innovációt, e fogalom mindegyik változatban központi helyet foglal el. A technológiai innováció lényegében új tudás létrehozása, vagy már létező tudáselemek kombinálása új módokon, és ezek transzformációja gazdaságilag szignifikáns termékekbe vagy gyártási folyamatokba. Az innnovációs rendszer folyamataiban igen sokféle szereplő vesz részt. Az innovációs tevékenységek magukban foglalják a tapasztalat általi tanulást (,learning by doing”), melynek révén a termelési eljárások hatékonysága növekszik, a használat eredményezte tanulást (, learning by using"), melynek eredményeként a komplex rendszerek használatának hatékonysága emelkedik, és az együttmüködés általi tanulást (,learning by interacting”), amely magában foglalja a felhasználók és termelök általi együttmüködés eredményezte termék-innovációkat.

A rendszerszerú megközelítés szerint az innováció mindenütt jelenlévő (ubiquitous) jelenség. A gazdaság minden szegmensében jelenlévő tanulás, keresés és kutatás folyamatai új termékeket, új technikákat, új szervezeti formákat és új piacokat eredményeznek. Ez a „mindenütt jelenvalóság” megnyilvánul a folyamat fokozatos és kumulatív jellegében: az innováció úgy is tekinthetö, mint már létező lehetőségek és elemek újszerü felhasználása, hisz szinte minden innováció meglévő tudást kombinál újfajta módon.

$\mathrm{Az}$ innovációs rendszerek irányzatai ugyanakkor holisztikusnak is tekinthetők abban az értelemben, hogy az innováció létrejöttében szerepet játszó lényeges tényezök széles körét kívánják elemzéseikbe bevonni. A rendszer-szemléletü megközelítés lehetővé teszi, hogy nem pusztán gazdasági, de az innovációt meghatározó intézményi, szervezeti, társadalmi és politikai tényezöket is az elemzés körébe vonjanak. Ebben az értelemben az irányzat interdiszciplinárisnak tekinthetỏ. Az innovációs rendszer egyes elemei, mint például a vállalatok, különböző körülmények között különbözőképpen viselkednek. E jelenség megértésében az innovációs rendszerek irányzatát jellemző strukturális és aktor-orientált szemlélet igen fontos szerepet tölt be.

$\mathrm{Az}$ intézményi megközelítés az innovációs rendszerek irányzatának második lényeges dimenziója. Az irányzat egyik legfeltünőbb jellegzetessége az intézmények szerepének hangsúlyozása. Mindazonáltal az egyes irányzatok intézményfogalma lényeges változatosságot mutat. Az intézmények fogalma meglehetősen heterogén és komplex, mely nemcsak normákat, szabályokat foglalhat magában, hanem különféle szervezeteket is. Más irányzatoknál viszont a vállalatok és az innovációban részt vevő ipari kutató laboratóriumok, vagy olyan támogató intézmények, mint a kutató egyetemek, kormányzati kutatóintézetek és a technológia-politika tartozik az innovációt meghatározó intézmények körébe.

$\mathrm{Az}$ innovációs rendszerek országonként meglehetős változatosságot mutatnak. Mindezeken túlmenően a rendszerelemeknek tekintett szervezetek és intézmények különbözhetnek nemcsak országonként, de akár régiónként vagy iparáganként is. $\mathrm{Az}$ innovációs rendszerek irányzatában nem a különbözőségektöl való elvonatkoztatás, hanem azok hangsúlyozása a lényeges. Mindezek miatt a különbözö 
Ács J. Zoltán - Varga Attila : Térbeliség, endogén növekedés és innováció.

Tér és Társadalom 14. évf. 2000/4. 23-38. p.

rendszerek összehasonlítása nem pusztán természetes, de kifejezetten szükségszerü is. Ugyanakkor, mivel a fejlödés során a tanulási folyamatok meghatározó szerepet játszanak, az innováció rendszerei az állandó változás állapotában vannak, s így az optimális rendszer meghatározása nem lehetséges. A rendszer soha nem éri el az egyensúly állapotát.

Az állam és a közösségi szektor nemzeti keretekben gyökereznek és nemzeti határok definiálják befolyásuk földrajzi kiterjedését. A nemzeti innovációs rendszerekre fordított kiemelt figyelmet a termelési rendszerek és az általános intézményi berendezkedés nemzetgazdaságonként eltéró jellegének felismerése magyarázza. Konkrétabban, a történelmi múltban, a nyelvben és a kultúrában megjelenö alapvető különbözőségek visszatükrözödnek a vállalatok belső szervezetében, azok egymás közti kapcsolataiban, a közösségi szektor szerepében, a pénzügyi rendszer intézményi berendezkedésében és a kutatás-fejlesztés szervezeteiben észlelt nemzeti sajátosságokban. A nemzeti innovációs rendszerek koncepcióját gyakorlatilag szimultán módon Lundvall (1988), Freeman (1988) és Nelson (1988) proponálta, majd ennek részletes vizsgálata Lundvall (1992) és Nelson (1993) köteteiben történt meg. Ezen utóbbi két mủ szemlélete jelentös különbözőségeket mutat. Míg Lundvall munkáján az interaktív tanulás elméleteinek hatását érezni, addig a Nelson-i közelítésmódot az evolucionarista szemlélet jellemzi.

Nelson könyvének egyik központi kérdése arra vonatkozik, hogy vajon ,tartható-e napjainkban, és ha igen, mennyiben a nemzeti rendszer koncepciója". Ebben a vonatkozásban Nelson két problémát tart szem elött. Elöször is, hacsak az innováció elemzése nem követ kifejezetten szük szempontokat, az innováció nemzeti szintü analízise elkerülhetetlenül a munkapiacok, a pénzügyi rendszer és a pénz-és kereskedelempolitika vizsgálatához vezet. Ugyanakkor az is elképzelhető, hogy a nemzeti szint egyrészt túlságosan tágnak bizonyul, hiszen azon politikai intézkedések, amelyek a j-edik iparágat támogatják, lehetséges, hogy nem megfelelőek a k-adik iparág számára, másrészt a nemzeti rendszer fogalma akár túlságosan szủknek is bizonyulhat, mivel bizonyos intézmények esetleg nemzetközileg fejtik ki hatásukat. A nemzeti innovációs rendszerek koncepciója problematikussá válhat Lundvall szerint is, hiszen mind a globalizáció, mind a vele egyidóben jelentkezö regionalizáció gyengíti a nemzeti államot. Mindazonáltal Lundvall (1992) éppen a nemzeti államok meggyengült pozíciója okán javasolja a nemzeti szintủ vizsgálatot.

Mindezek után természetszerüleg adódik az innovációs rendszerek alapegységére vonatkozó kérdés. Melyik szint a legmegfelelöbb az innovációs rendszerek definiálására: a nemzet, az ipari ágazat, a technológia, a régió vagy pedig a globális dimenzió? Természetesen mindez részben függ a nemzetállam méretétöl. Kis államok esetén a rendszer esetlegesen túlnő az állam határain, míg nagy országoknál a nemzeti határok valószínüleg túlságosan tágak. Mindazonáltal a globalizáció kiterjedésével a regionális szint megerösödésének számos oka van. A nemzeti államok diszfunkcionalitása például elősegíti a regionális szinten jelentkező gazdasági érdekközösségek megjelenését (Acs-de la Mothe-Paquet 1996). 
A következỏ szimultán folyamatnak lehetünk tanúi napjainkban: egyrészt a gazdaságok (éppen a globalizáció terjedése következtében) egyre kevésbé korlátozottak nemzeti határaik által, másrészt földrajzi specializáltságuk fokozatosan növekszik (Krugman 1995). Az innováció lényeges elemei egyre inkább regionálisak, mint nemzetiek. Ez a folyamat még lényegesebb a tudományra alapozott csúcstechnológiai iparágakban. Számos nagyvállalat gyengíti az anyaországgal fenntartott kapcsolatok intenzitását, miközben innovációs aktivitását különböző regionális innovációs rendszerek felé terjeszti ki. Ugyanakkor a vállalatok regionális hálózatai a tanulásnak és a termelésnek új formáit fejlesztik ki. Mindezek a változások igen jelentős kihivást jelentenek a nemzeti innovációs rendszerek tradicionálisan domináns szerepével szemben.

\section{Epilógus: „a regionális gazdasági növekedés új modellje” felé?}

Mindhárom, tanul mányunkban áttekintett irányzatnak megvannak azok az elemei, amelyek, legalábbis legjobb reményeink szerint, egy egységes elméletbe integrálódva a modernkori regionális gazdasági növekedés megfelelö magyarázat kínálhatják. Krugman modellje olyan technikát kínál, amely a gazdasági folyamatok térbeli koncentrálódásának magyarázatát néhány paraméter kiinduló kombinációinak következményeként írja le. Mindazonáltal a modell jelenlegi formája nem tünik alkalmasnak arra, hogy a tudás-bázisú regionális növekedés magyarázatául szolgáljon. Először is Krugman határozott ragaszkodása ahhoz, hogy tartózkodjék a technológiai externáliák (tudás szpillóverek) beépítésétől a modellbe, megakadályozza azok használatát az innovációk által generált regionális növekedés magyarázatára. Másodszor, míg a modell igen jól kidolgozott abban a tekintetben, ahogyan az a koncentrációk induló feltételeit megadja, a gazdasági növekedés leírásában már kevésbé tekinthető hasonlóan részletezettnek.

Az endogén gazdasági növekedés Romer által megalapozott iskolája a technológiai tudás szerepét hangsúlyozza a modernkori gazdasági növekedés folyamatában. Az endogén növekedés-elmélet egyik legfontosabb alapfeltevése abban áll, hogy a tudás azon része, amely közösségi jószágnak minősül, bárki számára rendelkezésre áll. Meg kell azonban jegyezni, hogy ez az állítás nem nyert megerösítést a tudás szpillóverek igen dinamikusan fejlődő empirikus irodalmában. Az ủj technológiai tudás (ami természetszerüleg a legértékesebb tudás az innováció folyamatában) általában még nem kodifikált, s pusztán személyes kapcsolatok által közvetíthetö. Úgy tünik tehát, hogy a tudás azon halmaza, amelyet nem másokat kizárónak nevezünk két részhalmazra bontható: a tökéletesen hozzáférhetö részre, amely tudományos publikációk, szabadalmi dokumentumok tanulmányozása révén bárki számára hozzáférhető és az eredetien új, de ugyanakkor még nem kodifikált, rejtett tudásra, amely pusztán a tudás befogadásához szükséges ismeretekkel rendelkezők személyes kapcsolatai által transzferálható. Míg az első halmazba tartozó tudáselemek bárki számára megszerezhetőek, a második halmaz elemeihez való hozzáférés korlátozott az innovációs rendszer szereplöi közti interakciók természete által. A sze- 
Ács J. Zoltán - Varga Attila : Térbeliség , endogén növekedés és innováció.

Tér és Társadalom 14. évf. 2000/4. 23-38. p.

36 Ács J. Zoltán-Varga Attila

TÉT XIV. évf. $2000 \square$

mélyes kapcsolatok gyakoriságának viszont gátat szab a térbeli távolság, következésképpen a legújabb tudás áramlása a térben korlátozottnak tünik.

Az innovációs rendszerek irányzata egy gondolkodási keret, amely az innováció elemzésében jól használhatónak bizonyult mind a tudomány képviselói, mind az innováció-politikával foglalkozók számára. Habár az innovációk rendszerének irányzata nem tekinthetö formalizált és megalapozott elméletnek, annak kialakulására kétségtelenül hatást gyakoroltak olyan innováció-elméletek, mint az interaktív tanulás teóriája, vagy az evolucionarizmus elmélete. Az elmúlt évek eröfeszítései arra irányultak, hogy az evolucionarista gazdaságtan elméleti és empirikus megfigyeléseit egy olyan koncepcionális keretbe szürjék át, amely a lazán értelmezett „nemzeti rendszer” gondolata körül szervezödve alkalmassá válik innovációpolitikai lépések támogatására. A nemzeti innovációs rendszerek koncepciója mindazonáltal meglehetősen problematikusnak tủnik. Míg napjaink gazdasági rendszerei (éppen a globalizáció terjedése következtében) egyre kevésbé korlátozottak nemzeti határaik által, addig e rendszerek földrajzi specializáltsága fokozatosan növekszik. Az innováció lényeges elemei egyre inkább regionálisak, mint nemzetiek.

Tanulmányunkban azt sugalljuk, hogy a gazdasági folyamatok koncentrálódásának kiinduló feltételeit megadó Krugman-i teória, az endogén gazdasági növekedés Romer-i elmélete és az aktorok szisztematikus együttműködését hangsúlyozó innováció-tan egy meghatározott kombinációja lehet az út a technológia által vezetett regionális fejlődés új elméletének kidolgozásához.

\section{Jegyzet}

'A szerzőpárosnak az International Regional Science Rewiev-nál "Geography, endogenous growth and innovation" címmel megjelenés alatt álló tanulmányának magyar változata.

\section{Irodalom}

Acs, Z. (2000) (ed.) Regional Innovation, Knowledge and Global Change. Pinter, London.

Acs,Z-Audretsch, D.-Feldman, M. (1991) Real effects of academic research: comment. - American Economic Review. 81. 363-367. o.

Acs, Z.-Audretsch, D.-Feldman M. (1994) R\&D spillovers and recipient firm size. - The Review of Economics and Statistics. 76. 336-340. o.

Acs, Z.-de la Mothe, J.- Paquet, G. (1996) Regional Innovation: In Search of an Enabling Strategy. The Implications of Knowledge-Based Growth for Micro-Economic Policies. -Howitt, P. (ed.), Calgary Press, Calgary, Alberta.

Aghion, P.-Howitt, P. (1998) Endogenous growth theory. MIT Press, Cambridge, Mass.

Anselin, L.-Varga, A.-Acs, Z. (1997) Local Geographic Spillovers between University Research and High Technology Innovations. - Journal of Urban Economics. 42. 422-448. o.

Arrow, K (1962) The economic implications of learning by doing. - Review of Economic Studies. 29. 155-173. o.

Barro, R,-Sala-i-Martin (1995) Economic Growth. McGraw-Hill, New York.

Bertuglia, C.-Lombardo, S,-Nijkamp, P. (1997) (eds.) Innovative Behaviour in Space and Time. Springer, Heidelberg.

Blaug, M. (1979) The German hegemony of location theory: a puzzle in the history of economic thought. - History of Political Economy. 11.(1.) 3-11. o. 
Blaug, M. (1992) (ed.) Johann von Thünen (1783-1850) Pioneers in economics. Aldershot, Hants: Elgar (An Elgar reference collection).

Braczyk, H.-Cooke, P.-Heidenreich, M. (1998) (eds.) Regional Innovation Systems. The Role of Governances in a Globalized World. UCL Press, London.

Dixit, A.-Stiglitz, J. (1977) Monopolistic competition and optimum product Diversity. - American Economic Review. 67. 297-308. o.

Edquist, C. (1997) Systems of Innovation. Cassel, London.

Fischer, M.-Varga, A. (2001) Technological innovation and interfirm cooperation. An Exploratory analysis using survey data from manufacturing firms in the metropolitan region of Vienna. International Journal of Technology Management. (forthcoming).

Freeman, C. (1988) Japan, a new system of innovation. Technical Change and Economic Theory. -Dosi, G.-Freman, C.-Nelson, R.- Silverberg, G.-Soete, L. (eds.) Pinter, London.

Fujita, M.-Krugman, P.-Venables, A. (1999) The Spatial Economy. MIT Press. Cambridge, MA, London.

Glaeser, E.-Kallal, H.-Sheinkman, J.-Shleifer, A. (1992) Growth in cities. - Journal of Political Economy. 100. 1126-1152. o.

Greenhut, M.-Norman, G. (1995) Introduction. The Economics of Location. Aldershot.

Grossman, M.-Helpman, E. (1991) Innovation and growth in the global economy. MIT Press, Cambridge, Mass.

Helpman, E. (1992) Endogenous macroeconomic growth theory. - European Economic Review. 36. 237-267. o.

Henderson, V. (1985) Economic theory and the cities. Academic Press, Inc., Orlando.

Hirschman, A (1958) The Strategy for Economic Development. Yale University Press, New Haven, Conn.

Isard, W. (1956) Location and space-economy. Wiley-MIT Press.

Isserman, A. (1996) „It's obvious, it's wrong, and anyway they said it years ago"? Paul Krugman on large cities. - International Regional Science Review. 19. (1\&2.) 37-48. o.

Jaffe, A. (1989) Real effects of academic research. - American Economic Review. 79. 957-970. o.

Judd, K. (1985) On the performance of patents. - Econometrica. 53. 567-586. o.

Krugman, P. (1980) Scale economies, product differentiation, and the pattern of trade.- American Economic Review. 70. 950-959. o.

Krugman, P. (1991a) Geography and Trade. MIT Press, Cambridge, MA.

Krugman, P. (1991b) Increasing returns and economic geography. - Journal of Political Economy. 99. (3.) $483-499.0$.

Krugman, P. (1993a) First nature, second nature, and metropolitan location. - Journal of Regional Science. 33. 129-144. o.

Krugman, P. (1993b) On the number and location of cities. - European Economic Review. 37. 293-298. o.

Krugman, P. (1993c) On the relationship between trade theory and location theory. - Rewiev of International Economics. 1. 110-122. o.

Krugman, P. (1995) Development, Geography and Economic Theory. MIT Press, Cambridge, MA.

Krugman, P. (1996) Urban concentration: the role of increasing returns and transport costs. International Regional Science Review. 19. 5-30. o.

Kuhn, T. (1984) A tudományos forradalmak szerkezete. Gondolat, Budapest.

Lucas, R. (1988) On the mechanics of economic development. - Journal of Monetary Economics. 22. 3-42. 0 .

Lundvall, B. (1988) Innovation as an interactive process: From user-producer interaction to the national system of innovation. Technical Change and Economic Theory. - Dosi, G.-Freman, C.-Nelson, R.Silverberg, G.-Soete, L. (eds.), Pinter, London.

Lundvall, B. (1992) (ed.) National Systems of Innovation. Pinter, London.

Maddison, A. (1987) Growth and slowdown in advanced capitalist economies. - Journal of Economic Literature. 25.649-698. o.

Martin, R. (1999) The new "geographical turn" in economics: some critical reflections. - Cambridge Journal of Economics. 23.65-91. o. 
Ács J. Zoltán - Varga Attila : Térbeliség , endogén növekedés és innováció.

Tér és Társadalom 14. évf. 2000/4. 23-38. p.

Martin, R.-Sunley, P. (1996) Paul Krugman's geographical economics and its implications for regional development theory: a critical assessment. - Economic Geography. 72. (3.) 259-292. o.

Mothe, de la, J.-Paquet, G. (eds.) (1998) Local and Regional Systems of Innovation. Kluwer Academic Publishers, Boston.

Myrdal, G. (1957) Economic Theory and Under-developed Nations. Duckworth, London.

Nelson, R. (1988) Institutions supporting technical change in the United States. Technical Change and Economic Theory. - Dosi, G.-Freman, C.-Nelson, R.-Silverberg, G.-Soete, L. (eds.), Pinter, London.

Nelson, R. (1993) (ed.) National Innovation Systems. Oxford, New York.

Nelson, R.-Winter, S. (1982) An Evolutionary Theory of Economic Change. Cambridge, Harvard University Press.

Nijkamp, P. (1997) Innovative behaviour in space and time. Springer, Heidelberg. 213-238. o.

Nijkamp, P.-Poot, J. (1997) Endogenous technological change, long run growth and spatial interdependence: a survey. Innovative Behaviour in Space and Time. - Bertuglia, C.-Lombardo, S,Nijkamp, P. (eds.), Springer, Heidelberg.

Ohta, H. (1988) Spatial price theory of imperfect competition. Texas A\&M University Press, College Station, Texas.

Oinas, P.-Malecki, E.J. (1999): Spatial Innovation Systems. Making Connections. Technological Learning and Regional Economic Change.-Malecki, E.J.-Oinas, P. (eds.), Ashgate, Aldershot. 261-275. o.

Romer, P. (1986) Increasing returns and long-run growth. - Journal of Political Economy. 94. 1002-1037. o.

Romer P. (1990) Endogenous technological change. - Joumal of Political Economy. 98. S71-S102. o.

Romer, P. (1994) The origins of endogenous growth. - Journal of Economic Perspectives. 8. 3-22. o.

Saxenian, A. (1994) Regional advantage: culture and competition in Silicon Valley and Route 128. Harvard University Press, Cambridge, MA.

Solow, R. (1956) A contribution to the theory of economic growth. - Quarterly Journalof Economics. 70. $65-94.0$.

Solow, R. (1957) Technical change in an aggregative model of economic growth. - International Economic Review. 6. 18-31. o.

Sternberg, R. (1999) Innovative linkages and proximity: empirical results from recent surveys of small and medium sized firms in German regions. - Regional Studies. 33. 529-540. o.

Varga, A. (1998) University Research and Regional Innovation: A Spatial Econometric Analysis of Academic Knowledge Transfer. Kluwer Academic Publishers, Boston.

Varga, A. (2000) Local academic knowledge spillovers and the concentration of economic activity. Journal of Regional Science. 40. 289-309 o.

Weber, A. (1929) The theory of the location of industries. University of Chicago.

\section{GEOGRAPHY, ENDOGENOUS GROWTH AND INNOVATION}

\section{ZOLTÁN J. ÁCS - ATTILA VARGA}

If we are to understand why some regions grow and others stagnate there are three fundamental questions that need to be answered. First, Why and when does economic activity become concentrated in a few regions leaving others relatively underdeveloped? Second, What role does technological change play in regional economic growth? Third, How does technological advance occur, and what are the key processes and institutions involved? In order to answer these three questions we survey three separate and distinct literatures that have a long and distinguished history, and all three have been recently reexamined. They are: the new economic geography (Krugman 1990), the new growth theory (Romer 1990), and The new economics of innovation (Nelson 1993). 